\title{
POLYMORPHISM OF PROLAMIN PROTEINS IN SELECTED VARIETIES OF WINTER WHEAT REGISTERED IN THE CZECH REPUBLIC
}

\author{
T. Vyhnánek
}

Received: July 10, 2008

\begin{abstract}
VYHNÁNEK, T.: Polymorphism of prolamin proteins in selected varieties of winter wheat registered in the Czech Republic. Acta univ. agric. et silvic. Mendel. Brun., 2008, LVI, No. 5, pp. 221-226

In 2006 and 2007 samples of harvested grain were used to verify the possibility of distinguishing 12 winter wheat genotypes and of detecting impurities on the basis of polymorphism of prolamin kernel proteins. Uniform electrophoretic patterns were detected in genotypes of Athlet, Buteo, Dromos, Ebi, Etela, Florett, Livia, Simila wheat in 2006 and 2007. On the basis of the identity index two sister prolamin lines with different share, depending on the year of harvest, were discovered in 3 wheat genotypes (Astella, Brea and Hana). The proportion of sister gliadin lines in the Astella and Brea genotypes was the same in both years. There was only minor difference $( \pm 2.5 \%)$ in the share of the sister lines in the Hana variety between the respective years, and could be influenced by environmental factors. A foreign genotype was detected in the Mona variety. The identity index of the impurity to the Mona variety $(i i=0.30)$ was considerably low. In the impurity the gliadin block Gld $1 B 3$ was not detected, which is the genetic marker of rye translocation T1BL.1RS (the Sr31 gene of resistance to black rust, higher cold resistance and the marker of poor baking quality - presence of secalin genes). The results proved the potential practical application of the electrophoretic detection of polymorphism of prolamin proteins as markers of impurities of foreign genotypes in a seed sample.
\end{abstract}

winter wheat, prolamin proteins, electrophoresis, admixture

In breeding work it is important to make sure to use initial seed stock that has the required properties, but also to use material of corresponding varietal (genotypic) purity. This also applies to farmers who produce and sell seeds and, last but not least, it concerns the processing industry where admixtures of an undesirable genotype have a negative effect and result in poorer quality of the end product.

Wheat (Triticum aestivum $\mathrm{L}$.) is a self-pollinating crop with a low share of cross-pollination (4-5\%). This means that most of the varieties are of the line type or they are a mixture of isogenic lines (Chloupek, 2000). A number of methods can be used to detect the impurities in a sample of harvested seeds; e. g. the polymorphism of storage kernel proteins - prolamins. High polymorphism of prolamins was used by many authors (Černý et al., 1992; Metakovsky, 1991; Pan et al., 2007; Wei et al., 2007) and is characteristic of these proteins.
Compared to other biochemical markers, the prolamins are not so dependent on conditions of the external environment and they are independent on the ontogenetic stage of the plant. Other markers, which are undergoing considerable development at the present time, monitor the level of DNA polymorphism. However, compared to the detection of polymorphism of prolamin proteins these methods are much more expensive due to the used chemicals and technology (Koch, 1998).

In terms of the above-mentioned aspects, polymorphism of storage proteins is suitable for the detection of varietal purity in kernel samples. The objective of the present study was to assess the varietal purity from samples of harvested seed stock using electrophoretic detection of the polymorphism of prolamin proteins of wheat. 


\section{MATERIALS AND METHODS}

Harvested kernels of twelve genotypes of winter hexaploid wheat $(2 n=6 x=42$, genome AABBDD)
(Tab. I) were used as experimental material (certified seed only).

I: Analysed wheat varieties

\begin{tabular}{|c|c|c|c|}
\hline Variety & Year of registration & Country of origin* & Pedigree \\
\hline Astella & 1995 & SVK & Viginta x SO-80-2208 \\
\hline Athlet & 1996 & GER & Granada x B-9875 \\
\hline Brea & 1996 & CZE & BR-918 x Hana \\
\hline Buteo & 2006 & GER & (LP 4285.90 x LP 3273.87) x Pegassos \\
\hline Dromos & 2006 & GER & (ZE 8710 x Batis) x Kimon \\
\hline Ebi & 1997 & GER & Line $81-4$ x Urban \\
\hline Etela & 2006 & CZE & HE $3691 \times$ Apollo \\
\hline Florett & 2006 & FRA & PBIS 95-82 x G31 \\
\hline Hana & 1985 & CSK & NS-984-4 x (Mironovskaja 808 x Moisson) \\
\hline Livia & 1991 & SVK & K-3758-1-76 x Kosutka \\
\hline Mona & 1994 & CZE & Iljicovka x L-6508-74 \\
\hline Simila & 2006 & CZE & Samanta $\mathrm{x}$ Estica \\
\hline
\end{tabular}

* CSK - Czechoslovakia; CZE - Czech Republic; FRA - France; GER - Germany; SVK - Slovakia

Wheat seeds harvested on experimental plots of the Central Institute for Supervising and Testing in Agriculture (Brno) in 2006 and 2007 were analysed using the vertical polyacrylamide electrophoresis Multigel-Long (Biometra, GER) according to the method of ISTA (International Seed Testing Association, 1999; Vyhnánek and Bednář, 2003). From each genotype 40 randomly selected seeds were analysed, each one separately (one seed = one electrophoretic lane). The resulting electrophoreograms were qualitatively interpreted using REM (relative electrophoretic mobility) where the reference band was the specific wheat protein with a 55 REM mobility, which can be found in all D-genome hexaploid wheat (Kozub et al., 2003). Quantitative interpretation was based on the intensity of the colouring of protein bands in the resulting electrophoretic pattern (Černý and Šašek, 1996). If heterogeneous patterns appeared, the identity index (ii) for the determination of the relation of electrophoretic patterns was estimated (Hadačová et al., 1980). These patterns were plotted using MS Excel by REM and intensity of the colouring of protein bands. Genetic interpretation of the results was based on Metakovsky et al. (1986).

\section{RESULTS AND DISCUSSION}

By means of prolamin polymorphism, it was possible to distinguish all the 12 genotypes of winter wheat. Uniform electrophoretic patterns were detected in genotypes of Athlet, Buteo, Dromos, Ebi, Etela, Florett, Livia, Simila wheat in 2006 and 2007. Černý and Šašek (1996) indicated that the polymor- phism of prolamin seed proteins is high compared to the other important fraction of wheat proteins - glutenins. Using electrophoretic separation of gliadins Metakovsky and Branlard (1998) characterised and differentiated French varieties approved and registered in the past 25-50 years.

On the other hand, heterogeneous patterns consisting of two prolamin lines were discovered in genotypes of Astella, Brea and Hana wheat in both years. Metakovsky et al. (2000) assessed the variability in 100 varieties registered in Spain in the past 40 years and detected several varieties with more than one sister line. The gliadin protein with REM 55 appeared in all the analysed genotypes (Fig. 1 and 2), confirming that all samples contain the D-genome of hexaploid wheat. In the Brea and Hana varieties differences in gliadins with a higher molecular weight - $\omega$-gliadins were detected, which constitute a part of the prolamin electrophoretic pattern with REM ranging between 8 and 44 . In contrast, differences in the area belonging to $\alpha-, \beta-, \gamma$-gliadins with a lower molecular weight in the REM area ranging between 80 and 100 were found in the Astella variety.

In the heterogeneous genotypes the identity index ranged from 0.80 to 0.85 (Tab. II) proving that the genotypes are sister prolamin lines (Šašek et al., 1990). By means of starch electrophoresis Šašek et al. (1998) achieved the same results in the Astella, Brea and Hana varieties. The proportion of sister gliadin lines in the Astella and Brea genotypes was the same in both years. There was only minor difference $( \pm$ $2.5 \%)$ in the share of the sister lines in the Hana variety between the respective years, and could be influenced by environmental factors. 


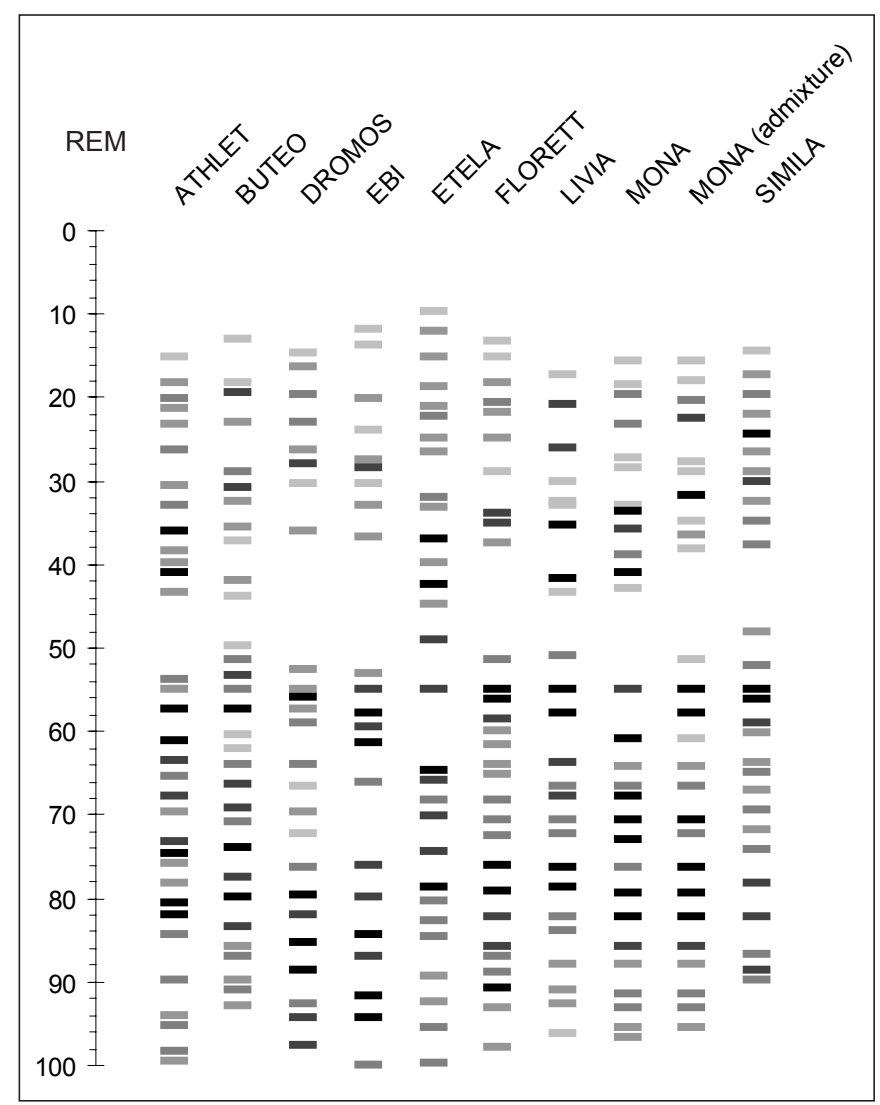

1: Prolamin patterns of single-line varieties of winter wheat

\begin{tabular}{|c|c|c|c|c|c|c|}
\hline $\begin{array}{r}\text { REM } \\
\end{array}$ & $\begin{array}{c}\text { ASTELLA } \\
\mathrm{A}\end{array}$ & $\begin{array}{c}\text { ASTELLA } \\
\text { B }\end{array}$ & BREA A & BREA B & HANA A & HANA B \\
\hline 10 & $=$ & $=$ & & & $=$ & - \\
\hline & $=$ & - & $=$ & $=$ & - & $=$ \\
\hline 20 & 픔 & 픔 & $=$ & $=$ & $=$ & - \\
\hline & - & - & - & - & - & $=$ \\
\hline 30 & $=$ & $=$ & - & $=$ & - & - \\
\hline & $=$ & $=$ & - & - & - & - \\
\hline 40 & - & & & - & & \\
\hline 50 & $=$ & $=$ & - & - & - & - \\
\hline & E & $\equiv$ & $=$ & $=$ & $=$ & $=$ \\
\hline 60 & $=$ & $\bar{z}$ & 틀 & $\bar{E}$ & - & - \\
\hline & $=$ & $=$ & $=$ & $=$ & - & - \\
\hline 70 & $=$ & $=$ & $=$ & $=$ & - & - \\
\hline & - & - & - & - & - & - \\
\hline 80 & - & - & $=$ & $=$ & $=$ & $=$ \\
\hline & $=$ & 즌 & 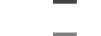 & 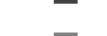 & - & - \\
\hline & $=$ & $=$ & 트 & 트 & $=$ & $=$ \\
\hline 90 & - & $=$ & & & $=$ & $=$ \\
\hline $100^{1}$ & & & & & $=$ & $=$ \\
\hline
\end{tabular}

2: Prolamin patterns of sister-lines of winter wheat varieties 
II: Share of prolamin lines in the analysed wheat genotypes

\begin{tabular}{|l|c|c|c|c|}
\hline \multirow{2}{*}{ Genotypes } & \multirow{2}{*}{ Years } & \multicolumn{2}{|c|}{ Share (\%) } & \multirow{2}{*}{$\begin{array}{c}\text { Identity index of } \\
\text { A and B lines }\end{array}$} \\
\cline { 3 - 5 } & & line A & line B & 0.80 \\
\hline \multirow{2}{*}{ Astella } & 2006 & 70.0 & 30.0 & \\
\cline { 2 - 5 } & 2007 & 70.0 & 15.0 & 0.85 \\
\hline \multirow{2}{*}{ Brea } & 2006 & 85.0 & 15.0 & 0.81 \\
\cline { 2 - 5 } & 2007 & 85.0 & 20.0 & \\
\hline \multirow{2}{*}{ Hana } & 2006 & 80.0 & 22.5 & \\
\cline { 2 - 5 } & 2007 & 77.5 & & \\
\hline
\end{tabular}

ISTA recommends using polymorphism of storage proteins in Triticum (International Seed Testing Association, 1999) as a method of determination of the varietal purity but does not mention limit values. Černý et al. (1992) determined the varietal authenticity and also detected varietal impurities of common wheat seeds using polyacrylamide gel electrophoresis. In our collection of varieties foreign genotype was detected in the Mona variety in 2006 only, and its share was 7.5\%. The foreign genotype had an electrophoretic spectrum with a markedly low identity index $(i i=0.30)$ compared to the analysed variety Mona. The genotype did not contain the gliadin cluster Gld 1B3 (REM 26-44) (Fig. 1). The presence of a foreign genotype in the Mona variety in 2006 could have been caused by insufficient purity of the used seed sample or a foreign genotype was introduced during harvest.

Characteristic for the Athlet, Etela, Livia and Mona varieties was a gliadin cluster genetically determined by the Gld 1B3 allele. According to Černý and Šašek (1996) this gliadin block represents the rye translocation TIBL.IRS in wheat, which is the marker of higher cold resistance, poorer baking quality (secalin genes in the wheat genome) and the Sr31 gene of resistance to black rust.

\section{ACKNOWLEDGMENTS}

I thank the Central Institute for Supervising and Testing in Agriculture (Brno) for providing of winter wheat samples. Vilém Reinöhl made useful comments concerning this manuscript.

\section{SUMMARY}

In 2006 and 2007 samples of harvested grain were used to verify the possibility of distinguishing and identification of 12 winter wheat varieties (Triticum aestivum $\mathrm{L}$., $2 \mathrm{n}=6 \mathrm{x}=42$, genome AABBDD) registered in the Czech Republic, and of detecting impurities on the basis of polymorphism of prolamin kernel proteins (gliadins). Polymorphism of gliadins were detected using polyacrylamide electrophoresis. By means of prolamin polymorphism, it was possible to distinguish all the 12 genotypes of winter wheat. Uniform electrophoretic patterns were detected in genotypes of Athlet, Buteo, Dromos, Ebi, Etela, Florett, Livia, Simila wheat in 2006 and 2007. On the basis of the identity index (ii) two sister prolamin lines $(i i=0.80-0.85)$ with different share, depending on the year of harvest, were discovered in 3 wheat genotypes (Astella, Brea and Hana). The proportion of sister gliadin lines in the Astella and Brea genotypes was the same in both years. There was only minor difference $( \pm 2.5 \%)$ in the share of the sister lines in the Hana variety between the respective years, and could be influenced by environmental factors. In the Brea and Hana varieties differences in sister prolamin lines in the pattern of $\omega$-gliadins (a higher molecular weight) were detected, which constitute a part of the prolamin electrophoretic pattern with REM ranging between 8 and 44. In contrast in the Astella variety, differences in the area belonging to $\alpha-, \beta-, \gamma$-gliadins with a lower molecular weight in the REM area ranging between 80 and 100 were found. In our collection of varieties foreign genotype was detected in the Mona variety in 2006 only, and its share was 7.5\%. The foreign genotype had an electrophoretic spectrum with a markedly low identity index $(i i=0.30)$ compared to the analysed variety Mona. In the impurity the gliadin block Gld 1B3 was not detected, which is the genetic marker of rye translocation T1BL.1RS (the Sr31 gene of resistance to black rust, higher cold resistance and the marker of poor baking quality - presence of rye secalin genes). The presence of a foreign genotype in the Mona variety could have been caused by insufficient purity of the used seed sample or a foreign genotype was introduced during harvest. Characteristic for four wheat varieties (Athlet, Etela, Livia and Mona) was a gliadin cluster genetically determined by the Gld 1B3 allele. The gliadin protein with REM 55 appeared in prolamin pattern in all the analysed varieties, confirming that all samples contain the D-genome of hexaploid wheat. The results of this work proved the potential practical application of the electrophoretic detec- 
tion of polymorphism of prolamin proteins for identification and distinction of wheat varieties, and as markers of impurities of foreign genotypes in a seed sample.

\section{SOUHRN}

Polymorfismus prolaminových bílkovin u vybraných odrůd ozimé pšenice registrovaných v České republice

V práci byla ověřena možnost rozlišení a identifikace dvanácti odrůd ozimé pšenice (Triticum aestivum L., $2 \mathrm{n}=6 \mathrm{x}=42$, genom AABBDD) registrovaných v České republice, a možnost zjištění příměsí na základě detekce polymorfismu prolaminových bílkovin (gliadinů) zrna ve vzorcích sklizených v letech 2006 a 2007. Pro detekci polymorfismu gliadinů byla využita polyakrylamidová elektroforéza. Všech dvanáct analyzovaných odrůd ozimé pšenice bylo pomocí elektroforetické detekce polymorfismu prolaminových bílkovin rozlišeno. Uniformní elektroforetická spektra byla v obou letech detekována u odrůd Athlet, Buteo, Dromos, Ebi, Etela, Florett, Livia a Simila. U tř́́ genotypů pšenice (Astella, Brea a Hana) byl detekován a na základě indexu identity (ii) zjištěn výskyt dvou sesterských prolaminových linií ( $i i=0,80-0,85)$ s různým zastoupením v závislosti na roku sklizně. U odrůd Astella a Brea bylo zastoupení sesterských linií v obou letech stejné. Pouze u odrůdy Hana byl zjištěn mezi jednotlivými roky malý rozdíl ( \pm 2,5\%). V př́ípadě odrůd Brea a Hana byly detekovány rozdíly u sesterských prolaminových linií ve spektru $\omega$-gliadinů (vyšší molekulová hmotnost), které se nachází v části prolaminového elektroforetického spektra s REM v rozmezí mezi 8 až 44. Oproti tomu u odrůdy Astella se sesterské prolaminové linie lišily ve spektru $\alpha-, \beta$-, $\gamma$-gliadinů s nižší molekulovou hmotností v rozmezí REM 80 až 100. V roce 2006 byla u analyzovaných odrůd detekována příměs u odrůdy Mona a její zastoupení bylo 7,5\%. Příměs měla výrazně nízký index identity k odrůdě Mona (ii = 0,30). U příměsi nebyl detekován gliadinový blok Gld 1B3 (REM 26-44), jež je genetickým markerem žitné translokace TIBL.IRS (genu Sr31 rezistence ke rzi travní, vyšší zimovzdornosti a markerem špatné pekařské jakosti - přítomnost žitných sekalinových genů). Přítomnost cizího genotypu u odrůdy Mona může být způsobena nedostatečnou čistotou použitého osiva nebo př́měsi během sklizně. Pro čtyři analyzované odrůdy pšenice (Athlet, Etela, Livia a Mona) byl charakteristický gliadinový klaster, který je geneticky determinován alelou Gld 1B3. Př́tomnost gliadinového proteinu s REM 55 v prolaminovém spektru všech analyzovaných odrůd znamená, že všechny analyzované odrůdy obsahují D genom hexaploidních pšenic. Výsledky práce ukazují možnost praktického využití elektroforetické detekce polymorfismu prolaminových bílkovin zrna při identifikaci a rozlišení odrůd pšenice a jako markerů příměsi cizího genotypu ve vzorku osiva.

ozimá pšenice, prolaminy, elektroforéza, př́měs

\section{REFERENCES}

ČERNÝ, J. a ŠAŠEK, A., 1996: Bílkovinné signální geny pšenice obecné. 1. vyd. Praha: ÚZPI: 42 s. ISBN 80-85120-55-0.

ČERNÝ, J., ŠAŠEK, A., KUBÁNEK, J. a SÝKOROVÁ, S., 1992: Identifikace odrůd pšenice obecné souběžnou elektroforézou gliadinů a podjednotek gluteninů s vysokou molekulovou hmotností. Genetika a Šlechténí, 28: 125-133. ISSN 0862-8629.

HADAČOVÁ, V., TURKOVÁ, V., HADAČ, E. and KLOZOVÁ, E., 1980: Comparison of seed proteins and lipid representatives of the genus Pisum from the point of view of their relationship. Biologia Plantarum, 22: 7-16. ISSN 0006-3134.

CHLOUPEK, O., 2000: Genetická diverzita, šlechtèní a semenárství. 2. vyd., Praha: Academia: 311 s. ISBN 80-200-0779-2.

INTERNATIONAL SEED TESTING ASSOCIATION, 1999: International Rules for Seed Testing. chapter VIII. Verification of species and cultivar: 41-43 and 252-254. ISBN 3-906549-27-5.

KOCH, G., 1998: Comparison of the efficiency of biochemical and molecular marker methods for the description of genetic diversity. Proceedings Sym- posium on the Utilisation of Genetic Resources, Gatersleben: 49-54. ISBN 92-9043-699-9.

KOZUB, N. A., SOZINOV, I. A. and SOZINOV, A. A., 2003: Recombination of gliadin genes of chromosome 1D in the common wheat hybrid carrying the introgression from Aegilops cylindrica. Plant Breeding, 122: 86-88. ISSN 0179-9541.

METAKOVSKY, E. V., 1991: Gliadin allele identification in common wheat. II. Catalogue of gliadin alleles in common wheat. Journal of Genetics and Breeding, 45: 325-344. ISSN 0394-9257.

METAKOVSKY, E.V. and BRANLARD, G., 1998: Genetic diversity of French common wheat germplasm based on gliadin alleles. Theoretical and Applied Genetics, 96: 209-218. ISSN 0040-5752.

METAKOVSKY, E.V., ACHMEDOV, M.G. and SOZINOV, A.A., 1986: Genetic analysis of gliadin - encoding genes reveals gene cluster as well as single remote genes. Theoretical and Applied Genetics, 73: 209-218. ISSN 0040-5752.

METAKOVSKY, E. V., GOMES, M., VAZQUEZ, J. F. and CARRILLO, J. M., 2000: High genetic diversity of Spanish common wheat as judged from gliadins alleles. Plant Breeding, 119: 37-42. ISSN 0179-9541. 
PAN, Z. F., DENG, G. B., ZHAI, X. G., WU, F. and YU, M. Q., 2007: Genetic diversity of Acid-PAGE monomeric prolamins in cultivated hulless barley (Hordeum vulgare L.) from Qinghai-Tibet plateau in China. Genetic Resources and Crop Evolution, 54: 1691-1699. ISSN 0925-9864.

ŠAŠEK, A., ČERNÝ, J. a BRADOVÁ, J., 1998: Elektroforetická spektra gliadinů a VMH podjednotek gluteninů odrůd pšenice obecné registrovaných v letech 1996 a 1997. Czech Journal of Genetics and Plant Breeding, 34: 95-101. ISSN 1212-1975.
ŠAŠEK, A., ČERNÝ, J., SÝKOROVÁ, S. a MALÝ, J., 1990: Gliadinové a gluteninové elektroforetická spektra některých nových šlechtění pšenice seté. Genetika a Šlechtèní, 26: 179-186. ISSN 0862-8629.

VYHNÁNEK, T. and BEDNÁŘ, J., 2003: Detection of the varietal purity in sample of harvested wheat and triticale grains by prolamin marker. Plant, Soil and Environment, 49: 95-98. ISSN 1214-1178.

WEI, E., PING, Y.L. JIA, L.X. and QIN, Ch., 2007: Extraction and identification of prolamin in different species seeds. Xibei Zhiwu Xuebao, 2007, 27: 21-27. ISSN 1000-4025.

Address

Ing. Tomáš Vyhnánek, Ph.D., Ústav biologie rostlin, Mendelova zemědělská a lesnická univerzita v Brně, Zemědělská 1,61300 Brno, Česká republika, e-mail: vyhnanek@mendelu.cz 